Szele, Bálint. "Translating Shakespeare for the Hungarian Stage: Contemporary Perspectives." Hungarian Cultural Studies. e-Journal of the American Hungarian Educators Association, Volume 6 (2013): http://ahea.pitt.edu DOI:

\title{
Translating Shakespeare for the Hungarian Stage: Contemporary Perspectives
}

\section{Bálint Szele}

\begin{abstract}
This paper presents trends in today's Shakespeare translation in Hungary based on interviews with Hungarian translators and scholars. Instead of a collection of names and dates of translators and translations, it focuses on the organic development of Hungarian Shakespeare translation, which has been going on for more than two hundred years, and tries to fit new developments into the tradition of translating Shakespeare in a theoretical framework. "Hungarian Shakespeare," now seen as a broad collection of Hungarian translations and adaptations, lives on, is kept alive in theaters, but it is undergoing a process of simplification. It was very hard work to do away with the forced prudishness and mannerism of the nineteenth century Shakespeare translations. After World War II, during the dominance of Communist culture, it was not allowed for several translations of Shakespeare to co-exist, so a politically appointed committee was set up to decide which one fit into the official canon. Only the selected texts could be printed and used in performances. After the political changes in Hungary in 1989, there was an upsurge of interest in Shakespeare, and since the 1990s there has been an unprecedented plurality of Shakespeare translations. I aim to examine the processes that led to the development of today's easy-to-understand and naturalistic translations, and to the abandonment of century-old classical ones.
\end{abstract}

Keywords: Shakespeare-translation, present-day Hungarian Shakespeare, Shakespeare in theater, text history and analysis

Biography: Bálint Szele is a professor of English literature at Kodolányi János College and also a literary historian who carries out research into the history of Hungarian literary translation, including the plays and poems of Shakespeare and the life and work of Hungarian literary translators. He has published two books, "Társalogni avval, aki bölcs" - 11 Shakespeare-interjú ['To converse with him that is wise' - 11 Shakespeare-interviews] (Ráció, 2008), which contains interviews with contemporary Shakespeare scholars and translators, and Szabó Lörinc Shakespeare-drámafordításai [Lőrinc Szabó's Shakespeare translations] (Semmelweis, 2012). His publications in English include essays on T.S. Eliot's poetry and on European integration.

\section{A Historical Overview}

If we have a look at its tradition, we can be surprised to see how much Hungarian Shakespeare translation has changed since the first attempts and, at the same time, how similar the translators' problems in the different periods are. The history of Hungarian Shakespeare translation began at the end of the 1700s when the first translations were made from German adaptations of Shakespeare to meet the demands of freshly-opened Hungarian theaters. The first 
Szele, Bálint. "Translating Shakespeare for the Hungarian Stage: Contemporary Perspectives." Hungarian Cultural Studies. e-Journal of the American Hungarian Educators Association, Volume 6 (2013): http://ahea.pitt.edu DOI: 10.5195/ahea.2013.121

plays to be translated were King Lear, Romeo and Juliet, and Richard II, although it would be more correct to call them adaptations rather than translations, as these texts lacked any kind of equivalence to the original in text structure or content. During that period it was already common practice in the German adaptations of Shakespeare as well as in further Hungarian translations to "naturalize" the plays, that is, to amend or change them to cater to the tastes of the Hungarian audience. To this end, violent scenes, murders, sexual or erotic references were omitted, and, for instance, King Lear was renamed Szabolcs vezér [Chieftain Szabolcs] to fit into Hungarian history. The Hungarian language of the 1700s was not yet flexible enough to render poetry and meaning even from a German adaptation so these texts are seen today as benevolent pioneering attempts to make Shakespeare known in Hungary.

From the mid-1820s, the so-called "Age of Reforms" began in Hungary and, after a long debate, in 1844 Hungarian became the official language of the country. Many people had to be taught Hungarian in an age when nationalism was the most progressive idea of the day and theaters were the most enthusiastic proponents of the Hungarian language. As there were not enough Hungarian playwrights, troupes needed to translate foreign plays, typically German ones, but during their research for texts they also discovered the "German Shakespeare," which had already been naturalized and considered by many Germans as Unser Shakespeare [Our Shakespeare]. Not much was known about Shakespeare's plays in Hungary at that time, and we must also note that there were hardly any people in Hungary who spoke English. The first proper translation of Macbeth was published in 1830 by Gábor Döbrentei, who was the first to use the English original text as his source. One year later, the Hungarian Academy of Sciences, established in 1827 "to strengthen, spread and refine the Hungarian language," set up a theatrical committee, which put twenty-two Shakespeare plays on its list containing seventy-one foreign plays worthy of translation. Besides selecting the plays, the committee also had the task of judging and awarding the finished translations, so it also had to concern itself with theoretical questions such as: should the translations be written in poem or prose, and what should be done with the frequent "impolite" parts of Shakespeare's plays? At that time, Hungarian literati were optimistic about their language being capable of rendering the English plays just as well as German. In 1836, Mihály Vörösmarty started to translate Julius Caesar into Hungarian, a feat considered to be heroic enough to get into the news sections of contemporary papers, and not without a reason since Vörösmarty, recognizing that form and meaning go hand by hand in Shakespeare's plays, was the first to attempt translating line for line, trying to keep an iambic rhythm in the lines. His perfect iambic translation of Antonius' famous speech ("I come to bury Caesar") is still familiar to Hungarian ears:

Temetni jöttem Caesart, nem dicsérni.

A rossz, mit ember tesz, túléli őt;

A jó gyakorta sírba száll vele.

Ez legyen Caesar sorsa is.

(Julius Caesar, Act 3, Scene 2)

[I come to bury Caesar, not to praise him.

The evil that men do lives after them;

The good is oft interred with their bones;

So let it be with Caesar.] 
Szele, Bálint. "Translating Shakespeare for the Hungarian Stage: Contemporary Perspectives." Hungarian Cultural Studies. e-Journal of the American Hungarian Educators Association, Volume 6 (2013): http://ahea.pitt.edu DOI: 10.5195/ahea.2013.121

All the while Vörösmarty complained that it was very hard to create a translation like his verse version, writing "it is by all means a challenging enterprise to translate Shakespeare" [Shakspeart fordítani minden esetre nagy vállalat $]^{1}$ (Vörösmarty 1983, 374). In the early years of literary translation in Hungary, it was not uncommon for translators as a form of captatio benevolentiae to complain about the difficulty of the task and to write apologies to preface their translations. While the chief objective of the early translators was to enrich the Hungarian language and literature through creating translations that were inventive and flexible enough to follow the original, by around the mid-eighteenth century another aspect began to prevail: getting to know another culture through translation. So, unlike Vörösmarty, Sándor Petöfi in his 1848 translation of Coriolanus, no longer felt it necessary to apologize for his translation. His natural, flexible language was capable of reproducing Coriolanus' curses ("You common cry of curs"):

Hitvány kutyák! kiknek lélekzetét Úgy gyülölöm, mint a büzhödt mocsárt, S kegyét becsülöm, mint a temetetlen Halott maradványát, mely légemet Megrontja: én számüzlek titeket! (Coriolanus, Act 3, Scene 3)

[You common cry of curs! whose breath I hate As reek $o^{\prime}$ the rotten fens, whose loves I prize As the dead carcasses of unburied men That do corrupt my air, I banish you; And here remain with your uncertainty!]

as well as the gentle language of the penitent Coriolanus ("Like a dull actor now"):

Feledtem szerepem,

Mint lomha színész, és úgy benn akadtam, Hogy szégyen. (Coriolanus, Act 5, Scene 3)

[Like a dull actor now, I have forgot my part, and I am out, Even to a full disgrace.]

From the 1860s, Shakespeare translators began to identify the important problems of translation, such as the number of syllables in a line, how to reproduce the rhymed parts, as well as the contrast of elevated feelings and low comedy within one play. A particular problem was the rendering of the numerous puns, all the more so if they were sexual ones. The famous Hungarian poet János Arany, undoubtedly the best Shakespeare translator of the second half of the

\footnotetext{
${ }^{1}$ All translations from Hungarian sources are mine.
} 
Szele, Bálint. "Translating Shakespeare for the Hungarian Stage: Contemporary Perspectives." Hungarian Cultural Studies. e-Journal of the American Hungarian Educators Association, Volume 6 (2013): http://ahea.pitt.edu DOI: 10.5195/ahea.2013.121

nineteenth century, who was also the first to formulate the general principles of Shakespeare translation during the 1850s, still insisted in his guidelines to other translators that if they were to keep the "obscene" parts, they had to do so with appropriate attenuation "so that scandal could be avoided as much as possible" [a botrányt a mennyire lehetséges, eltávolítani] (Arany 1966, 341). At the same time, especially in his private correspondence, he suggested that the censoring of the language was the theater director's not the translator's task, and Shakespeare's plays should be translated in their entirety.

I respect salons [i.e. of educated and rich Hungarians], but shall Sh.'s first complete translation be lame? (...) King John would have to be staged without the first act, in four acts, so that nobody would understand. (Not to mention Measure for Measure!)

[Tisztelem a szalonokat: dehát Sh. első teljes forditása csonka legyen? [...] János királyt az első felvonás nélkül kellene adni, 4 felvonásban, hogy senki se értse. (Hát még a Measure for Measure!)] (Arany 1984, 212)

Obviously, Arany and his colleagues felt the dilemma or choosing between philological faithfulness and the expectations of the public. Finally, they translated the full plays but, as we shall see, many of the erotic or vulgar references were simply disregarded.

Based on the principles laid forth by Arany, the first complete Hungarian Shakespeare was published between 1864 and 1878 by the famous and authoritative Kisfaludy Society in nineteen volumes, with usually two plays to a volume. These translations were both aimed at the reading public and theater companies. The sophisticated process of text edition, which involved the proofreading of the translations by two independent reviewers and giving the text back to the translators for correction, set the practical standards of what was and was not acceptable in a translation and also laid down the principles of how to review translations. Arany himself played a major role by reviewing five translations. Equivalence to the original in form and content was already seen as the norm, but even the editors of the series themselves knew that some translations did not live up to this standard, at the same time feeling that creating the Hungarian Shakespeare and competing with the Germans was more important at this point than the quality of the text. No doubt they realized that the translators of the time could not produce better translations (in fact, some were overburdened by the task) so the nineteen-volume edition was representative of the general standards of Hungarian literary translation and protected by the authority of the Kisfaludy Society, the most significant academic literary society of the period. However, even under the protection of the Society, from the 1900s most translations in the series came up for fierce criticism for being too romantic and genteel, as well as hard to understand and overcomplicated. We can quote one example from Othello, translated by Károly Szász, which demonstrates how complicated the structure and how un-Hungarian the text was (Othello, Act 1, Scene 3):

Atyja, szeretvén, gyakran hitt magához. Kérdezte életem történetét, Évrül évre, a sok ostromot, csatát, Mikbe forogtam. Elmondottam azt, Elsőtül végig, gyermekéveimtől A perczig, melyben épen kérdezé.
Her father loved me; oft invited me;

Still question'd me the story of my life,

From year to year, the battles, sieges, fortunes,

That I have passed.

I ran it through, even from my boyish days,

To the very moment that he bade me tell it; 
Szele, Bálint. "Translating Shakespeare for the Hungarian Stage: Contemporary Perspectives." Hungarian Cultural Studies. e-Journal of the American Hungarian Educators Association, Volume 6 (2013): http://ahea.pitt.edu DOI: 10.5195/ahea.2013.121

Beszéltem száz csapás s megindító Balsors felöl, mi szárazon s vizen Hányt és vetett; midőn hajszálon állt a Tenger csatáin életem; midőn Rabúl esvén az ellenség kezébe: Eladtak s újonnan kiváltatám.
Wherein I spake of most disastrous chances, Of moving accidents by flood and field Of hair-breadth scapes I' the imminent deadly breach, Of being taken by the insolent foe And sold to slavery, of my redemption thence (...)

The translation is one line longer that the original and contains structures alien to the Hungarian language, like the first line which reads in English "her father, loving me, oft invited me," or kérdezé, and kiváltatám, which represent tenses no longer used in Hungarian. There are also examples of outdated orthography (évrül, percz, vizen). Another example shows us how Shakespearean comedy was distorted in the nineteenth century. In a scene in Twelfth Night, Malvolio is talking about her mistress's "cut," which is an obvious reference to the female sex organ and "great P" to urination. The Hungarian translator József Lévay left it as C U T, which does not make any sense to the Hungarian public. The original Sir Andrew was seen as ignorant and dull, whereas the Hungarian one can show a genuine incomprehension, together with the Hungarian audience. There is nothing comic whatsoever in the Hungarian version, which simply takes the literal meaning of the text:

\section{MALVOLIO}

By my life, this is my lady's hand these be her very C's, her U's and her T's and thus makes she her great P's. It is, in contempt of question, her hand.

\section{SIR ANDREW AGUECHEEK}

Her C's, her U's and her T's: why that?

MALVÓLIÓ (a levelet felvéve)

Életemre, ez a kisasszonyom keze! Ezek éppenséggel az ö C-i, az ö U-i s az ö T-i; s épen így teszi a P-ket is. Ez, kérdésen kívül, az ö keze.

\section{ANDOR \\ Az ö C-i, az ö U-i, az ö T-i: mire való ez? (Twelfth Night, Act 2, Scene 5)}

From 1910 on, the poets associated with the modern trend-setting periodical Nyugat [West] felt it was time to summarize the up-to-date principles of Hungarian Shakespeare translation again. Mihály Babits, Dezső Kosztolányi, and their contemporaries appreciated Shakespeare's subtle and rich poetry and tried to accommodate it again in the Hungarian language. It was also in this period that the divergence of "literary" and "theatrical" Shakespeare began. Literary Shakespeare meant a text that kept all the complexities and metaphorical richness of Shakespeare's language even at the expense of clarity and was consequently harder to read and understand; it came to exist because it is a tradition in Hungary for poets without any knowledge of spoken English or the theater to translate plays. Theatrical Shakespeare meant an easy-tounderstand, "speakable" text that was more suitable for theater performances, left out a part of the literary subtleties of the text and was usually created or commissioned by theater directors (and were very rarely published). In the next decades, a new generation of translators was also brought up: in the 1930s Lőrinc Szabó made many natural-sounding and poetic translations, in 
Szele, Bálint. "Translating Shakespeare for the Hungarian Stage: Contemporary Perspectives." Hungarian Cultural Studies. e-Journal of the American Hungarian Educators Association, Volume 6 (2013): http://ahea.pitt.edu DOI: 10.5195/ahea.2013.121

the forties István Vas, now seen as one of the subtlest translators, and later László Kardos, György Somlyó, and others contributed to the unfolding of a new Hungarian Shakespeare based on philological exactness and literary inventiveness. Some of these new translations were finally published in 1948 in a four-volume edition, which was to become the first and last "capitalist" Shakespeare in Hungary. In this edition, thirty translations of the new generation of translators were collected but the edition also reproduced six of the earlier translations from the 1864-78 series (Hamlet, King John, and A Midsummer Night's Dream, translated by Arany, Coriolanus, translated by Petöfi, Julius Caesar and King Lear translated by Vörösmarty) which are today referred to as the six "Classical Translations."

The informal competition between "literary" and "theatrical" Shakespeare went on as the old translations got harder and harder to understand for the general audiences. Even though the Classical Translations were genial in their time and maintained a certain timeless value and beauty, they missed many of the features that make Shakespeare's plays so topical even today. Dezső Mészöly, a man of the theater and a witty translator of Shakespeare, was the advocate of a "new Hungarian Shakespeare." He translated eleven of the plays between 1946 and 1996, the most important ones being Romeo and Juliet, Othello, Anthony and Cleopatra, as well as Love's Labour's Lost, Measure for Measure, and Twelfth Night, and by the 1980s became an authority on Shakespeare translation. Mészöly criticized most earlier translations, including the Nyugat ones, for being un-theatrical and outdated. He insisted that "the chief criterion of faithfulness is the theatrical effect itself" [a forditás hüségének legföbb kritériuma éppen a szinpadi effektus] (Mészöly 1988, 15). To achieve this, he says, Shakespeare's text should be contemporary to the ears of the Hungarian audience. To this end, in his translations he used a clear, easy-tounderstand Hungarian language without any foreign words and also a certain pathos to heighten the words of the plays. He was a master of translating the humorous parts, as he had worked as a dramaturge for a long time, so he knew perfectly well which jokes and puns would work with the audience. Even so, partly due to the prudishness of literary officials, he often decided to soften the erotic or sexual elements in Shakespeare's plays.

In 1955, the heyday of Communism in Hungary, a new "Marxist" Shakespeare was published by Új Magyar Könyvkiadó [New Hungarian Publishing House]. What made the series Marxist was not the translations themselves but the metatextual apparatus of the forewords, afterwords, as well as the notes and comments. In this edition, the text of three classical translations was amended: Julius Caesar and King Lear, translated by Vörösmarty, amended skillfully by Lörinc Szabó; and Coriolanus, translated by Petőfi, amended by Gyula Illyés. Illyés was the greatest champion of protecting the classical translators by keeping their original translations in the canon with corrections and amendments. As Mária Borbás, the secretary of the committee of editors explained, when it came to the question whether it is sacrilege or not to amend classical translations, Illyés said there were two reasons for the so-called "sacrilege": one is that we are not committing it since we do not touch the original ideas of Petöfi or Vörösmarty (Szele 2008, 169). Illyés also said that the classical translators would have been happy about the amendments if they had known what the fate of their translations would be in a hundred years' time. He was an advocate of the "usefulness" of the plays and opted for "perfect" translations, which could be played in theaters. "When publishing the plays, we should not think of philologists but students and workers who want to enjoy Shakespeare, not literary gossip" [A kiadásnál ne filológusokra gondoljunk, de diákokra, munkásokra, akik Shakespeare-t akarják élvezni, nem az irodalom körüli pletykát] (Szele 2008, 170). Illyés was also very much concerned with what "workers and peasants" would understand from the texts. After a long debate, the committee of editors decided 
Szele, Bálint. "Translating Shakespeare for the Hungarian Stage: Contemporary Perspectives." Hungarian Cultural Studies. e-Journal of the American Hungarian Educators Association, Volume 6 (2013): http://ahea.pitt.edu DOI:

to publish the amended texts in the volumes and the original version in the endnotes. These amended versions of the texts later became the canonized versions in Hungarian literature and theater.

The creation of the new 1955 Shakespeare edition is surrounded by literary and political gossip about the various translators involved in its creation. The translation of Love's Labour's Lost (in Hungarian: A felsült szerelmesek) was started by Endre Gáspár who died suddenly and left the translation unfinished in the middle of a scene, so György Faludy was asked to finish the translation, which he did with all due respect. When it came to the next edition in 1961, Faludy had already fallen into political disgrace, had been sent to a labor camp, and finally left Hungary and so his half of the translation could not be published. So Dezső Mészöly was asked to finish the translation. Finally, in 1988, Mészöly's full translation was published under a new title: Lóvátett Lovagok. János Domokos, who worked at the publishing house where the translation came out, once noted that the comrades who were charged with "supervising literature" were happier with Mészöly's texts (Szele 2008, 177). This did not mean he was favored by the officials: in the Hungarian Kádárist cultural system of "Ban, Tolerate, Support" (in Hungarian these are referred to as the three T's: Tilt, Tür, Támogat) he fell into the category of tolerable, which means he was allowed to work and create new translations if it seemed necessary. In order to rehabilitate the poet Miklós Radnóti, a poet of Jewish origin killed in 1944, his unfinished Twelfth Night translation was completed by a translator of French literature, György Rónay, and published in 1948. There was another anecdote that shows the nature of incompetence in Communist dictatorship. When the preliminary pages of the new edition were shown to the director of the publishing house, Ferenc Rákos, who had earlier returned from a Moscow exile, he angrily asked the secretary if she knew who the greatest Hungarian classical translators were-Arany, Vörösmarty, Petöfi — because their names must be set in emphasized print. Absolutely hopeless, she went to a distinguished translator, Gábor Devecseri, who himself worked in the translating team and served as a major in the People's Army. As Borbás recalls, Devecseri put on his uniform, clomped into Rákos' office and "defended" the other translators in the edition so that the prelims contained the names of all translators in the same font size (Szele 2008, 178-9). The 1955 edition was available either in four or six volumes, the former being the "representative edition" (the most expensive layout cost $420 \mathrm{HUF}$ ), the latter, cheaper edition was available for anyone, even for ordinary workers (for 200 HUF). In 1961 a complete new edition was published in seven volumes, which added to the six volumes of the previous edition slight modifications and in a seventh volume Shakespeare's poems. The officially organized Shakespeare cult came to an end in 1988 when the last "Complete Plays of William Shakespeare" was published in four volumes, where the texts were almost the same as in the 1961 edition (together with the good old Classical Translations), with only three translations changed. The Hungarian Shakespeare had become rigid and outdated. Some of the translations published in 1955 and 1988 still indulged in being poetic and prose parts were still regarded as un-Shakespearean, which prevented translators, with the notable exception of Mészöly, from seeing the real value and importance especially of Shakespearean comedy (see also Szele 2006).

\section{New Perspectives in Shakespeare Translation}

The 1980s saw a kind of Shakespeare renaissance thanks to one of the new translators, István Eörsi, who re-translated three of the great "classics" (A Midsummer Night's Dream in 1980, Hamlet in 1983 and 2003, and Coriolanus in 1985) and also made a new translation of The 
Szele, Bálint. "Translating Shakespeare for the Hungarian Stage: Contemporary Perspectives." Hungarian Cultural Studies. e-Journal of the American Hungarian Educators Association, Volume 6 (2013): http://ahea.pitt.edu DOI: 10.5195/ahea.2013.121

Tempest in 1985 and Othello in 1988. The first of these new translations was ordered for the Kaposvár Theater by János Ács. As Eörsi commented,

During the prudish nineteenth century it was impossible to translate this maddeningly erotic Renaissance fairy tale, and the extremely shy János Arany was absolutely unfit for this job. He created a genial fairy tale... The slogan of sexual happy end, 'Lovers, to bed' was, in Arany's Hungarian translation 'Let's go to sleep, followers' - this one verse alone illustrates/proves that the play needed to be retranslated.

[A prüd 19. században nem lehetett hiven leforditani ezt a tébolyitóan erotikus reneszánsz tündérmesét, és a különösképpen szemérmetes Arany János különösképpen nem volt alkalmas erre a feladatra. Remekelt egy zseniális tündérmesét... A szerelmi happy end jelszava a ,Lovers, to bed” magyarul, Arany forditásában: „Alunni, hívek”- ez önmagában is bizonyítja, hogy ezt a darabot újra kellett fordítani] (Szele 2008, 118)

Eörsi's text finally became a mixture of classical and modern lines, because, as he said, he wanted a modern text with Renaissance spirituality, at the same time wanting to keep Arany's immortal lines, his direct hits (Szele 2008, 119). Unfortunately, his translation failed miserably, as Arany's text is a part of Hungarian national education, and the audience did not pay attention to the characters' conflicts but to the conflicts between the version they were familiar with and Eörsi's new translation. Eörsi went on to continue his translation work with Hamlet, but his translation was badly received, again for two reasons: first, because of the hypocritical and outdated idea that Arany's was the one and only Hungarian Hamlet, and second, because this also implied it was unpatriotic for anyone to touch Arany's work. As Eörsi's translation tried to modernize Arany's, his work was regarded by many critics subservient to the Party as "sacrilege" and Eörsi was called a traitor. A part of this debate was published in April, May, and June 1983 in the Hungarian literary weekly Élet és Irodalom [Life and Literature]. Eörsi defended himself by saying all plays are modern at the time of their birth so they must be retranslated from time to time; modern theater requires that the Shakespearean texts should not be made lyrical but should be simple and clear, without any clichéd prosiness (Eörsi 1993, 6). To Eörsi and other progressive theater men it had become clear that amending the classical translations would not work anymore, and so he re-translated Othello in 1988. When he was translating Othello, he commented, his primary task was to keep the feeling of the bestial passion of the original so that it does not take on a certain beauty in the stream of words, so that he could keep the impure stream of the English text, a kind of ugliness presented in the highest poetic manner (Szele 2008, 119). Eörsi also felt that more attention must be paid to metaphors and images and that they must be translated as close to the original as possible: "We must keep the essence of the metaphors of a play as historic time is contained in the metaphors" [Meg kell örizni a darabok metafora-kincsének lényegét, mert a metaforában benne rejlik a történelmi idö] (Szele 2008, 121). In contrast to the severe criticism Eörsi had received for his early translations, his powerful and outspoken later translations of The Tempest (1985) and Hamlet (2003) did win critical acclaim in Hungarian literary circles.

1989, the year following Eörsi's Othello translation, saw thorough political changes in Eastern Europe and brought the formal fall of socialism in Hungary. Freedom of speech became 
Szele, Bálint. "Translating Shakespeare for the Hungarian Stage: Contemporary Perspectives." Hungarian Cultural Studies. e-Journal of the American Hungarian Educators Association, Volume 6 (2013): http://ahea.pitt.edu DOI:

a declared right, censorship was abolished, new theaters were opened, and new ways of expression were sought, so that theaters soon found once again that they needed new Shakespeare texts to be able to achieve their artistic goals. With a few notable exceptions such as the popular plays Richard III and Macbeth, and lesser-known ones such as Timon of Athens, Henry V, and Troilus and Cressida, both amended classical and early twelfth century translations were now regarded as outdated. The best-known translator of the 1990s, who is still active, was Ádám Nádasdy, who started his career as a translator in 1994 preparing a new translation of $A$ Midsummer Night's Dream for Péter Gothár, director of Katona József Theater. Nádasdy was asked by the director to translate the play into a present-day Hungarian language. Nádasdy's translation made the daring move of a complete break with the classics, because, as he said, translations from the last century (including the nineteenth century and the beginning of the twentieth) were really 'century-old', very much old-fashioned. "I thoroughly enjoy them but they can not be presented on stage any more" [Nagyon élvezem öket, de színpadon elöadni ezeket ma már nem lehet] (Szele 2008, 14).

Nádasdy looks at Shakespeare as a dramatist who knows very well how to make characters speak, and how to distribute the lines among them. As Nádasdy is a linguist, he is very good at determining the actual style and register of Shakespeare's plays. As he says:

Other translators, because they cannot glimpse behind the lines, see Shakespeare as more literary, more archaic, more stylized because to those who speak present-day English, Shakespeare's text appears to be such - but of course it is not present-day English. So I can treat his text with more confidence, if you like, with more cheekiness, I can say 'yes, this is a cheap joke, this is slang, this line is uninteresting and prosaic, even banal' - banal is a very good word here. Because I [as a linguist] know the language of that age better, I might be better at sorting out what is banal and what is creative.

[Pontosan azért, mert nem tudtak annyira belehelyezkedni, ök az egészet egy kicsit irodalmiasabbnak, archaikusabbnak, stilizáltabbnak képzelték, mert aki a mai angolt ismeri, annak Shakespeare szövege ilyennek tünik - de persze nem mai angol. Ezért én bátrabban, vagy ha úgy tetszik, pimaszabbul tudok bánni Shakespeare szövegével, és azt tudom mondani, hogy igen, ez itt egy olcsó tréfa, ez itt egy szleng, ez itt egy érdektelen és prózai, banális sor - a banális itt nagyon találó szó. Talán, mivel jól ismerem a kor nyelvét, könnyebben veszem észre, hogy mi banális és mi kreatív] (Szele 2008, 33)

Neither is Nádasdy afraid of rude or colloquial language. Shakespeare uses the language of the street in the street scenes, and he did so, too, in his translation, as he puts it, "according to Shakespeare's intentions" (Szele 2008, 32). "I don't think poor Shakespeare should resemble a finishing school compared to the other plays, because he is not like that" [Nehogy már szegény Shakespeare valami lánygimnáziumnak hasson a többi mühöz képest, mert nem az] (Szele 2008, 39). Nádasdy's translating methods can be illustrated by taking the same excerpt from Twelfth Night that we have seen above and translating it back into English: 
Szele, Bálint. "Translating Shakespeare for the Hungarian Stage: Contemporary Perspectives." Hungarian Cultural Studies. e-Journal of the American Hungarian Educators Association, Volume 6 (2013): http://ahea.pitt.edu DOI:

MALVOLIO (fölveszi a levelet)

Ejha, ez az úrnőm kézírása! Így írja a „P”-t, az „,"-t, az „N”-et, az „A”-t, és pont ekkora a nagy „K”-ja. Kár is tovább vizsgálni: ez ő.

FONNYADI

„P”, ,I”, „N”, „A" - miért épp ezek?

The letters in the Hungarian text (P.I.N.A.) make up a vulgar and very obvious reference to the female sex organ, whereas "great $\mathrm{K}$ " is a familiar vulgarism for "prostitute" in Hungarian without actually pronouncing the word. In this translation it becomes easy to see how ignorant and dull Sir Andrew Aguecheek, whose name Nádasdy translated as Fonnyadi Ábris, is.

Nádasdy is not an armchair translator but is commissioned by theaters and this gives him the advantage of being able to consult directors, dramaturges and actors, who give him invaluable feedback about his texts. He knows to pay particular attention when it comes to translating Shakespeare's humor, which can be very hard to render into Hungarian, and many early translators failed by trying to force English Renaissance jokes on a Hungarian audience. Nádasdy considers himself an interpreter who is helping a foreign person - in this case, Shakespeareconvey his message. There are cases when, as he puts it,

the interpreter finds he cannot translate it or if he does so, it will not be funny in Hungarian. So he says something different, and also tells a joke which makes the audience laugh, so the guest can look at him thankfully thinking "what a good interpreter he is, he also translated the joke." In a certain sense, he is really a good interpreter because if the guest wants to sound funny, he must make the audience laugh at all costs. They might not have been laughing at the same thing, but who cares, it was just the tool that was different.

[a tolmács rájön, hogy vagy nem tudja lefordítani, vagy ha lefordítja, az magyarul nem lesz vicces. Ezért mond valami mást, és egy viccet is elmond egyben, amin felnevet a közönség, mire a vendég ránéz hálásan, hogy milyen jó tolmács, mert a viccet is lefordította. És bizonyos értelemben tényleg jó ez a tolmács, mert ha a vendég vicces akart lenni, akkor igenis meg kell nevettetni a hallgatóságot.

Legfeljebb nem pont ugyanazon nevettek, hát istenem, csak az eszköz volt más] (Szele 2008, 19)

Nádasdy's clear, natural language, his intelligent interpretations, his reserved poeticism (which he defines as "the text is only a little bit unnatural") make him the most authoritative and popular Shakespeare translator today. His extremely felicitous translations have started a new era in Hungarian Shakespeare translation, and an absolutely new way of looking at Shakespearean humor and comedy. It is no wonder he has already made nine translations, and they are the most important ones in the Shakespeare canon: A Midsummer Night's Dream (1994), The Comedy of Errors (1997), Hamlet (1999), The Taming of the Shrew (2000), Romeo and Juliet (2002), Twelfth Night (2005), As You Like It (2006), The Tempest (2007), and King Lear (2010). 
Szele, Bálint. "Translating Shakespeare for the Hungarian Stage: Contemporary Perspectives." Hungarian Cultural Studies. e-Journal of the American Hungarian Educators Association, Volume 6 (2013): http://ahea.pitt.edu DOI: 10.5195/ahea.2013.121

The other very important personality in re-interpreting Shakespeare in Hungary was János Csányi, a true man of theater, who felt the same urge as Nádasdy to re-translate some of the plays. As he said:

The social circumstances have changed several times since [Shakespeare's time]. Not only the language but also the living medium, the audience has changed, so it is obvious that these plays must be re-translated.

[A társadalmi környezet azóta többször megváltozott. Nemcsak a nyelv, hanem maga az élö közeg, a közönség alakult át, tehát nyilvánvalóan újra le kell fordítani ezeket a darabokat] (Szele 2008, 104)

When preparing for a performance of A Midsummer Night's Dream in 1994, Csányi, as had Nádasdy and his director, also realized that Arany's classical translation — which had been seen as the best for more than a century - had become almost incomprehensible for today's audience and has lost all of its direct meaning with which young people can be addressed (Szele 2008, 98). Csányi also pointed out that Arany's prudery had prevented him from conveying a significant part of the play's message, so that he decided not only to re-translate the play but also to make a shift in time and replace all the scenes involving the Mechanicals, as the world of the theater has also changed significantly. In an interview he stated:

Cutting all the scenes of the Mechanicals (except for one) I wrote fully new scenes and integrated them into the play. I hope it does not sound immodest but these were the most successful scenes in the performances.

[hanem kihúzva (egy kivételével) minden mesterember-jelenetet, egészen új jeleneteket írtam és illesztettem a darabba. Talán nem tünik szerénytelenségnek, de az elöadásnak ez volt az egyik legsikeresebb része] (Szele 2008, 106)

By actualizing the time of the play, Csányi endeavored to bring his translation closer to contemporary Hungarian audiences. Nádasdy and Csányi had very similar objectives but differed in their respective ways of achieving them. Csányi, an actor himself, thinks meter could be treated flexibly by the actor, whereas Nádasdy thinks if the actors make mistakes reciting his translation, it is obvious his text is not good enough. Nádasdy has a certain obsession about linguistic form, whereas Csányi thinks in terms of theatrical performance. As he emphasizes, Shakespeare plays on the stage, at the same time watching and living through his own character playing onstage from the crowd, and this is what clearly shows he was a real playwright: this can only be done by people who have a thorough experience of the theater with all its elemental correspondences and effects (Szele 2008, 102). Csányi also sees the so-called "cruxes" and inconsistencies of the Shakespearean play as natural elements of the Bard's effect-dramaturgy, as he calls it; Nádasdy thinks the text must be absolutely clear. Both translators mentioned in this section have contributed to the renewal of the Hungarian Shakespeare, and their respective translations of A Midsummer Night's Dream were published in the same leaflet in 1995 as an appendix to the periodical Szinház [Theater]. 
Szele, Bálint. "Translating Shakespeare for the Hungarian Stage: Contemporary Perspectives." Hungarian Cultural Studies. e-Journal of the American Hungarian Educators Association, Volume 6 (2013): http://ahea.pitt.edu DOI:

While Nádasdy and Csányi were creating their modern translations along very different lines from each other, András Forgách was commissioned by the Hevesi Sándor Theater around 1992 to make a "comprehensible version" of Shakespeare's (or, rather, Vörösmarty's) King Lear. Forgách re-translated a third and amended two-thirds of Vörösmarty's version, striving to keep what he referred to as the latter's "fantastic trouvailles," (Szele 2008, 45) such as the following lines:

Cordelia mit tegyen? Hallgat s szeret. (King Lear, Act 1, Scene 1), or

Fújj, szél, szakadj meg, fújj, dühöngj! Vihar,

Felhő, omoljatok le, míg a tornyot

S a szélvitorlát elsüllyesztitek!

Ti gondolatnál gyorsabb kéntüzek,

Kengyelfutói a tölgyhasgató

Mennykőnek, hamvasszátok el

Ez ösz fejet! Világot rengető

Villám, döngesd laposra e kemény,

Kerek világot! Rombold el a

Természet mühelyét s egyszerre fojts meg

Minden csírát, miből a háladatlan

Ember keletkezik! (King Lear, Act 3, Scene 2)

Forgách believes that Vörösmarty's text still presents such a richness in the theater that if the spectator only perceives a fifth of the meanings, it still provides a maddening richness (Szele 2008, 48). Around 2002 Forgách also made a new translation of Anthony and Cleopatra for Enikő Eszenyi's theater company, but this time he admits that he submitted himself to the director's and the actors' desire for an up-to-date version and ended up creating what to him was an overly modern text, which he ultimately decided not to publish. As István Géher, the bestknown Hungarian Shakespeare scholar said in an interview, theaters are still interested in Shakespeare and there is a natural tendency for the director to desire a new text for each premiere. In the last few decades it has been the director who instructs the translator in what kind of translation to produce, and translations made this way fulfill their functions very well in the theater (Szele 2008, 139).

There are plays in the Hungarian Shakespeare canon (e.g. Timon of Athens, Cymbeline, Pericles, etc.), which had their accepted translations from 1955 but had never been staged, so there had never been a need to amend or even to criticize them. However, when it came to staging Henry VI Part III for the first time in Pécs, the director realized that the 1955 text was no longer adequate for a performance in 1999, so András Imreh was asked to make a new translation for the premiere. Just to present another famous example before we go on, we must note that one of the most acknowledged classical translations, Arany's Hamlet, first published in 1867 , is a play which is well-known to many even today, but to pay attention to it for two hours and understand what is going on and what is being said onstage is an enormous task, which only those members of the audience who are familiar with both Shakespeare's original text and Arany's translation are able to do (Szele 2008, 73). When Imreh was asked about how he had dealt with the erotic parts of his new translation, he said "these are probably the most porous parts of the translations because they are based on the erotic reference system of present-day 
Szele, Bálint. "Translating Shakespeare for the Hungarian Stage: Contemporary Perspectives." Hungarian Cultural Studies. e-Journal of the American Hungarian Educators Association, Volume 6 (2013): http://ahea.pitt.edu DOI: 10.5195/ahea.2013.121

Hungarian, and nobody knows if they are going to be understood in a decade's time" [Valószínüleg ezek a forditás legporózusabb részei, mert ezek tényleg a mai magyar nyelv erotikus utalásrendszerére épülnek. Ki tudja, hogy egy évtized után is érthetöek lesznek-e még] (Szele 2008, 75). As an example of how Imreh dealt with one such scene, see the example of Richard and Clarence speaking about the king's lust for Lady Grey using metaphors from fencing, which are very hard to translate and understand in Hungarian, so that Imreh provided several versions for the director (shown with a /):

RICHARD III. (Aside to Clarence)

Ay, widow? then I'll warrant you all your lands, An if what pleases him shall pleasure you.

Fight closer, or, good faith, you'll catch a blow.

RICHÁRD (félre, Georgehoz):

Nocsak, özvegyecske! Meglesz a földed,

Ha jó neked, ami jó a királynak.

Kerülj közel, és belefutsz a nyársba / Zárd soraid, vagy behatol az ellen.

(Henry VI Part III, Act 3, Scene 2)

As we have seen, there are two contradicting tendencies in today's Hungarian Shakespeare translation, one that tries to salvage the classical translations in as much as possible, the other opting for modernizing the plays, which leads to a permanent need for new translations. Kálmán Ruttkay, the most influential expert in Hungary on Shakespeare, said of the modernizing translations that:

today translators do their work according to the wishes of the actors - in my view, beyond measure. Yes, it is easy to recite these texts but this illusion is deceitful. Shakespeare is not an easy author. A process of popularization has begun.

[A fordító pedig aládolgozott a színésznek, szerintem túlságosan is. Így könnyü mondani a szöveget, de ez hamis illúzió: Shakespeare nem könnyü szerzö. Elindult egyfajta popularizálási folyamat] (Szele 2008, 131)

A famous poet, Szabolcs Várady, who is also a Shakespeare translator having brilliantly translated The Winter's Tale in 2006, expresses a view contrary to that of Ruttkay, opining that

Arany's Shakespeare is also an organic part of Hungarian literature, and as such, it is sacred, if you like. I see the dramatic effect of his Hamlet as a whole as unsurpassable. But if today's Hungarian theater culture can not cope with it, if it can only approach and do something with the play in a living, modern language, it is natural that the text needs to be re-translated.

[Arany Shakespeare-je a magyar irodalomnak is szerves része, és mint ilyen „szent”, ha úgy tetszik. Az ö Hamletjének én egészében a drámai erejét is felülmúlhatatlannak látom. De ha a mai színházkultúra nem tud vele megbirkózni, ha csak éló, mai 
Szele, Bálint. "Translating Shakespeare for the Hungarian Stage: Contemporary Perspectives." Hungarian Cultural Studies. e-Journal of the American Hungarian Educators Association, Volume 6 (2013): http://ahea.pitt.edu DOI:

nyelven tud a darab közelébe férkőzni, és egyáltalán kezdeni vele valamit, akkor természetesen újra kell fordítani] (Szele 2008, 84)

He also believes that archaic language should only be used if the author's original text does the same. If the author uses the living language of his own age, the translation must be of the same material, and if he also uses slang, translators must not be afraid to use it (Szele 2008, 88).

György Spiró, who translated Shakespeare's Richard II, among many other foreign plays, says Shakespeare uses many rude effects in his plays which are to be considered simply as "theatrical." Shakespeare was not a genteel poet but an entertainment professional, he adds (Szele 2009), meaning that to be able to keep that entertainment value, translators need to update his plays relatively freely.

It is quite clear that traditional translations, in spite of all their beauty, are losing ground in Hungary. In today's Hungarian theater, Shakespeare's metaphor-burdened language is a nuisance so theatre people try to simplify the texts, consequently making them colorless. When Nádasdy Ádám published his translation of A Midsummer Night's Dream, he said he wanted the so-called poetic style to disappear, that is, his aim was to make a text in which the audience cannot even notice there is style or there is text, to which István Géher replied that if Nádasdy was referring to Shakespeare's poetic mannerism, he was right, but if he meant that he would reduce Shakespeare's poetic richness of meanings that would be a great loss (Szele 2008, 137). Today's translations try to cater for more direct and naturalistic dialogues, ones that actors can easily interpret and recite and spectators can easily understand. However, Géher also adds that "this is not right as polysemy is a characteristic feature of Shakespearean language" [ez nem helyes, mert a shakespeare-i nyelvnek a természete ez a sokjelentésüség] (Szele 2008, 147). Géza Kállay agrees with Géher's view, adding that:

the message of Shakespeare philology to translators could be that they must be brave, that they must be afraid neither of the fact that a sentence can be understood in several ways, nor when they manage to create an image which is not exactly there in the original because such is the nature of the Shakespearean text.

[A Shakespeare-filológia legfontosabb üzenete az lehetne a Shakespeare-fordítók felé, hogy legyenek bátrak, ne féljenek attól, ha egy mondatot sokféleképpen lehet érteni, és attól sem, ha egy olyan helyen sikerül egy képet létrehozniuk, ahol az eredetiben nincs. Ilyen a shakespeare-i szöveg természete] (Szele 2008, 162)

Hopefully, in future translations there will be a way to maintain Shakespeare's poetic richness in the modern Hungarian language. The two Shakespeares, "literary" and "theatrical," have separated for good. The Hungarian Shakespeare lives on, it is kept alive in theaters, but it is undergoing a process of simplification. The older, canonized texts (which had been prepared with much effort and a series of corrections) still occupy the printed pages but the old canon has become rigid and useless for the theater. The new translations are created randomly, upon commission from a theater, and most of them, with the exception of Eörsi's and Nádasdy's texts, remain unpublished. As we have seen, the first period of Hungarian Shakespeare translation was about learning how to translate and setting the standards. This was achieved so successfully that nineteenth century Shakespeare translations dominated theaters until the 1930s. At the beginning of the twentieth century there were translators who translated for their own poetic pleasure and 
Szele, Bálint. "Translating Shakespeare for the Hungarian Stage: Contemporary Perspectives." Hungarian Cultural Studies. e-Journal of the American Hungarian Educators Association, Volume 6 (2013): http://ahea.pitt.edu DOI:

others who made modern translation for the stage, such as Lörinc Szabó, who in the 1930s became something like an in-house translator for the Hungarian National Theater, creating four new translations which meant a paradigm change with their intellectual rigor and natural language. It was very hard work to do away with the forced prudishness and mannerism of nineteenth century Shakespeare. After World War Two Communist culture did not tolerate the co-existence of several texts, that is why official committees were set up to decide which translation was the best and which one fitted and did not fit into the canon. It is no wonder that theater directors and dramaturges would always cut and change these texts, naturally within the limits allowed by censors. There have been no attempts to renew this fossilized printed Hungarian Shakespeare corpus since 1988. But theater translations proliferate, for example Romeo and Juliet or King Lear have had several translations in the last ten years, some by Dániel Varró, one of Nádasdy's students. There is still demand for Shakespeare in Hungary, but the new Shakespeare is more naturalistic and much less poetic. Whether the new translations will become part of the Hungarian literary canon or whether there will be a canon at all is a question that remains to be answered.

\section{Works Cited}

Arany, János. 1966. Arany János összes müvei. XIII. kötet: Hivatali iratok 1 [The Complete Works of János Arany. Volume 13. Office Documents]. Budapest: Akadémiai.

Arany, János. 1984. "Levél Szász Károlynak, 1859. márc. 19.” [Letter to Károly Szász, 19 March 1859]. Magyar Shakespeare-tükör. Ed. Maller Sándor and Ruttkay Kálmán. Budapest: Gondolat.

Eörsi, István. 1993. "Shakespeare-fordításaim elé" [Preface to my Shakespeare Translations]. William Shakespeare: Hamlet. Trans. István Eörsi. Budapest: Cserépfalvi.

Mészöly, Dezső. 1988. Új magyar Shakespeare. Fordítások és esszék [New Hungarian Shakespeare. Translations and Essays]. Budapest: Magvető.

Szele, Bálint. 2006. “A komédia feltámasztása (A Vízkereszt fordításairól)” [Resuscitating Comedy (About Translations of Twelfth Night)]. Jelenkor 49.2 (June 2006): 658-664.

Szele, Bálint. 2008. "Társalogni avval, aki bölcs" - 11 Shakespeare-interjú ['To converse with him that is wise' - 11 Shakespeare-interviews]. Budapest: Ráció.

Szele, Bálint. 2009. "Ha elöre tudom, nem vállaltam volna" [If I had known I wouldn't have undertaken it]. Interview with György Spiró. Szabadpart 39. (Summer 2009). 10. Aug. 2013. <http://www.szabad-part.hu/39/39_irodalom_szele.html>

Vörösmarty, Mihály. 1983. "A fordító jegyzete a Julius Caesarból közölt mutatványokhoz" [The Translator's note to the excerpts from Julius Caesar]. Vörösmarty Mihály összes müvei. 12. kötet: Drámafordítások [The Complete Works of Mihály Vörösmarty. Volume 12. Drama Translations]. Budapest: Akadémiai. 